\section{SCOPE OF IMPROVING MECHANICAL CHARACTERISTICS OF CONCRETE USING NATURAL FIBER AS A REINFORCING MATERIAL}

\author{
Sristi Das Gupta*, MD. Shahnewaz Aftab, Hasan Mohammod Zakaria , \\ Chaity Karmakar
}

Department of Civil Engineering, Ahsanullah University of Science and Technology, Bangladesh
Article history

Received

12 March 2020

Received in revised form

04 May 2020

Accepted

30 May 2020

Published online

31 July 2020

\author{
*Corresponding author \\ Sristi.ce@aust.edu
}

\begin{abstract}
Using natural (Jute) fiber in concrete as a reinforcing material can not only augment the concrete strength but also restrict the use of synthetic fiber which is environmentally detrimental. To achieve this goal, this study evaluated compressive strength, tensile strength and plastic shrinkage of concrete incorporating 'Natural (Jute)' fiber of different length (15 mm and $25 \mathrm{~mm}$ ) with various mix proportions of $0.10 \%, 0.2 \%, 0.3 \%$ and $0.4 \%$ respectively by volume of concrete. Concrete is vulnerable to grow shrinkage cracks because of high evaporation rate in dry and windy conditions. Incorporating of fibers could abate development of this crack. The large length $(25 \mathrm{~mm}$ ) and higher content (? $0.3 \%$ ) of reinforcing materials (jute fiber) result to the lowering of mechanical properties of JFRC compare to plain concrete. But in the incorporation of short (15 $\mathrm{mm})$ and low fiber content ([ $0.3 \%$ ), enhances the mechanical properties of the same JFRC. Inclusion of $0.3 \%$ (15 mm length) fiber gave maximum enhancement of both concrete compressive and tensile strength by $12.4 \%$ and $58 \%$ respectively compared to the non-fiber reinforced concrete. A drastic suppression of crack occurrence and area of crack between non-fiber reinforced concrete and fiber reinforced concretes was attained. Experimental results of incorporating $0.1-0.4 \%$ fiber with $15 \mathrm{~mm}$ length in concrete revealed that plastic shrinkage cracks were decreased by $75-99 \%$ in contrast to non-fiber reinforced concrete. Therefore, it is concluded that the incorporation of jute fiber in making FRC composite would be one of the favorable methods to enhance the performance of concrete.
\end{abstract}

Keywords: Fiber reinforced concrete; Natural Fiber; Compressive strength; Tensile strength; Plastic shrinkage

(C) 2020 Penerbit UTM Press. All rights reserved

\subsection{INTRODUCTION}

Plain concrete exhibits a very low resistance against tension with limited ductility and little resistance to cracking. Internal micro cracks are intrinsically present in the concrete and due to its deficient strength the enlargement of such micro cracks, eventually leading to brittle failure of the concrete. The structural micro cracks develop in plain concrete or similar brittle materials, even before loading. This is mainly due to plastic shrinkage or other factors of volume change. The structural cracks propagate at a slow speed because they are hindered by various obstacles, change of direction by evading the more resistant grains in matrix. The development of such micro cracks is the main cause of inelastic deformations in concrete (Madhuri M. et al; 2017). It has been recognized that the addition of small, closely spaced and uniformly dispersed fibers to concrete would act as crack arrester and would substantially improve its static and dynamic properties. The impression of using fibers as reinforcement is not new. Fibers have been used as reinforcing material since archaic times. From the past, the idea of composite materials came using horsehair and fiber reinforced concrete was one of the topics of concerned. Eventually, the practice of fiber cementitious or concrete composites mixed with metallic or non-metallic fibers had been greatly made in fields of high rise building and infrastructures in order to ameliorate additional requirements of high ductility, performance and durability (Kim J S. et al; 2017). For fiber-reinforced composites, non-metallic fibers such as synthetic fibers were incorporated to mainly develop high post cracking ductility. The polymeric fibers viz. polypropylene, polyethylene, polyester, acrylic and aramid fibers are becoming popular these days (Kannan S; 2016). Now a days, the sustainable development with higher strength is the growing demand of construction industry. Concrete reinforced by natural fibers are more encouraging to assure the concrete strength enhancement with no perilous impact on environment. In addition to, the productive use of available 
natural assets can also be insured. Between two different types of fibers, i.e., natural fibers and artificial polymer-based fibers, natural fibers are pledging to use as reinforcement to stun the intrinsic deficiencies in FRC reinforced with synthetic fiber. The main defects associated with the use of synthetic fibers are relatively high cost and health and environmental imperilment. On the other hand, natural fibers which are biodegradable, cheap, environmentally friendly, and easily available as reported by Zakaria et al. (2016) are cultivated from naturally available resources, for example, coconut tree, banana tree, cotton, and jute. Therefore, making good-quality and low- cost sustainable FRC for housing the requirements to employ natural fibers are expanding. Variety of factors influences mechanical properties of FRC reinforced with natural fiber. Among these factors, the type of fiber and their characteristics have a significant influence on the mechanical properties of these composites (Jarabo et al. 2012). Jute fibers, which come from annual plants, are available in abundance in Bangladesh. Hence, it is necessary to examine the effect of enlarging the potential use of natural (jute) fiber for obtaining enhanced concrete with low cost, without affecting the environment and minimum health imperilment. Therefore, the main focus of the study is to incorporate jute fiber to reinforce concrete composites and to evaluate the effect of fiber length and content (volume fraction) on its mechanical behavior

\subsection{MATERIALS AND METHODS}

\subsection{Cement}

The experimental works were performed using ordinary portland cement (OPC) of strength class $52.5 \mathrm{~N}$ in which the percentage of gypsum in the cement was $5 \%$.

\subsection{Aggregates}

In this research, locally available material for instance, sand used as fine aggregate and stone chips was used as coarse aggregate as well as aggregate grading was performed according to ASTM C33. A nominal maximum coarse aggregate size of $20 \mathrm{~mm}$ was used for this study. The properties of FA and CA are shown in Table 1.

Table 1 Physical properties of aggregates

\begin{tabular}{lll}
\hline \multicolumn{1}{c}{ Property } & Sand & Stone chips \\
\hline Bulk Specific Gravity (OD Basis) & 2.54 & 2.66 \\
\hline Absorption Capacity, (\%) & 1.34 & 0.69 \\
\hline Fineness Modulus (FM) & 2.62 & - \\
\hline
\end{tabular}

\subsection{Fiber}

The unprocessed jute fiber was collected from local branch shown in Fig. 1. This jute fiber with two different lengths (15 and $25 \mathrm{~mm}$ ) also shown in Figure 1 were utilized with various percentages $(0.1,0.2,0.3$ and $0.4 \%)$ on concrete mixture. The Characteristics of the jute fiber are shown below (Table 2):

Table 2 Properties of jute fiber used in the experimental works (textileengineeringstudy. 2012).

\begin{tabular}{ll}
\hline Length $(\mathrm{mm})$ & 15 \\
Length $(\mathrm{mm})$ & 25 \\
\hline Diameter $(\mathrm{mm})$ & 0.05 \\
\hline Aspect Ratio $(\mathrm{I} / \mathrm{d})$ & 300 \\
Aspect Ratio $(\mathrm{I} / \mathrm{d})$ & 500 \\
\hline Density $(\mathrm{kg} / \mathrm{m} 3)$ & 1400 \\
\hline Tensile Strength $(\mathrm{MPa})$ & 400 \\
\hline Color & Off-white to brown \\
\hline Elongation at break \% & 1.7 \\
\hline
\end{tabular}

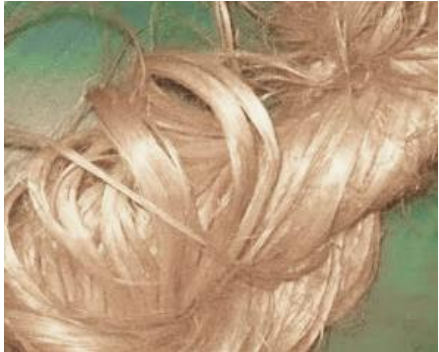

(a)

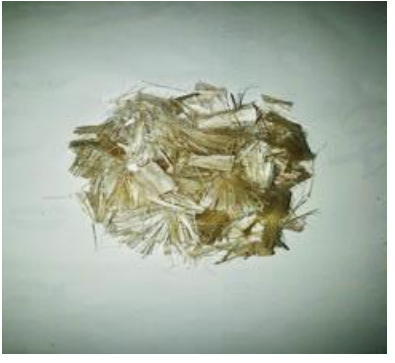

(b)

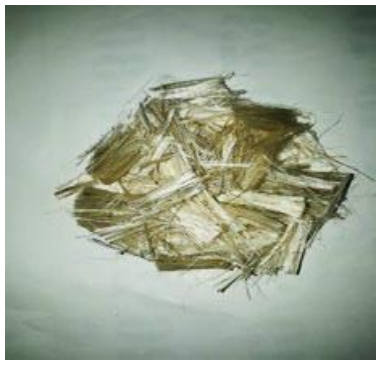

(c)

Figure 1 (a) Raw Jute Fiber, (b) Jute Fiber (15 mm), (c) Jute Fiber (25 mm)

\subsection{Mix Proportioning}

Concrete mixtures were finalized after various trial mixing to achieve the target strength of $35 \mathrm{MPa}$ (at 28 days) with the desire slump value of 75-100 mm. The mix design was followed by American Concrete Institute ( $\mathrm{ACl} 211,2009)$. The overall mix proportions of concrete ingredients to develop JFRC are presented below in Table 3. 
Table 3 Mix proportions of the concrete used in experimental works (jute fiber)

\begin{tabular}{|c|c|c|c|c|c|c|}
\hline \multicolumn{2}{|c|}{ Type of Mixing } & $\begin{array}{l}\text { Water } \\
\left(\mathrm{kg} / \mathrm{m}^{3}\right)\end{array}$ & $\begin{array}{l}\text { Cement } \\
\left(\mathrm{kg} / \mathrm{m}^{3}\right)\end{array}$ & $\begin{array}{l}\mathrm{CA}\left(\mathrm{kg} / \mathrm{m}^{3}\right) \\
\text { [SSD] }\end{array}$ & $\begin{array}{l}\mathrm{FA}\left(\mathrm{kg} / \mathrm{m}^{3}\right) \\
\text { [SSD] }\end{array}$ & $\begin{array}{l}\text { Amount of } \\
\text { Fiber }\left(\mathrm{kg} / \mathrm{m}^{3}\right)\end{array}$ \\
\hline \multicolumn{2}{|c|}{ Plain Concrete (0\%) } & 215 & 566 & 999 & 565 & 0.0 \\
\hline \multirow{4}{*}{$\begin{array}{c}\text { Jute } \\
(15 \mathrm{~mm})\end{array}$} & JF1 (0.1\%) & 217 & 566 & 999 & 565 & 2.345 \\
\hline & JF2 (0.2\%) & 218 & 566 & 999 & 565 & 4.690 \\
\hline & JF3 (0.3\%) & 221 & 566 & 999 & 565 & 7.035 \\
\hline & JF4 (0.4\%) & 222 & 566 & 999 & 565 & 9.380 \\
\hline \multirow{4}{*}{$\begin{array}{c}\text { Jute } \\
(25 \mathrm{~mm})\end{array}$} & JF5 (0.1\%) & 216 & 566 & 999 & 565 & 2.345 \\
\hline & JF6 (0.2\%) & 218 & 566 & 999 & 565 & 4.690 \\
\hline & JF7 (0.3\%) & 221 & 566 & 999 & 565 & 7.035 \\
\hline & JF8 (0.4\%) & 223 & 566 & 999 & 565 & 9.380 \\
\hline
\end{tabular}

\subsection{Mixing and Casting}

In this study, the different fiber length of 15 and $25 \mathrm{~mm}$ and the proportions of $0,0.1,0.2,0.30$, and $0.4 \%$ were used volume of concrete (Islam S. G M et.al; 2016). Initially, suitable quantity of coarse aggregate (CA), fine aggregate (FA) and cement were mixed for 2 minutes. Furthermore, saturated surface dry (SSD) condition of both coarse and fine aggregate were ensured before dry mixing. Afterwards, jute fibers of desired proportion were mixed at a slow rate so that even distributions of the mixing can be ensured. To the end, water is added to the mix compound in which mixing was done for total of 4 minutes. Generally, mixing of concrete was performed using concrete machine mixture. After that, the slump test was conducted to evaluate the workability of the concrete composite. Concrete mold of $150 \times 150 \times 150 \mathrm{~mm}$ was prepared to evaluate the performance of concrete under compression and tension loading. During the placement of concrete in the mold, tamping was done using an appropriate tamping rod as well as a steel trowel was used to produce the smooth finish surface. Subsequently, the specimens were remained in mold for $24 \mathrm{~h}$ after casting. Finally, the concrete samples were discharged from the molds and immersed in clean water for the curing process.

\subsection{Compressive Strength Testing}

Examination of concrete compressive strength was carried out after curing of 7 days and 28 days concrete specimens. The compressive test was followed according to EN 12390-3 (2009). Evaluation of compressive strength can yield a promising and obvious suggestion about the influence on strength with the fiber volume increment in concrete. In this study, load was implemented at a strain rate of $1.5 \mathrm{~mm} / \mathrm{min}$ progressively till the failure of specimens occur. Compressive test setup is shown in Figure 2.

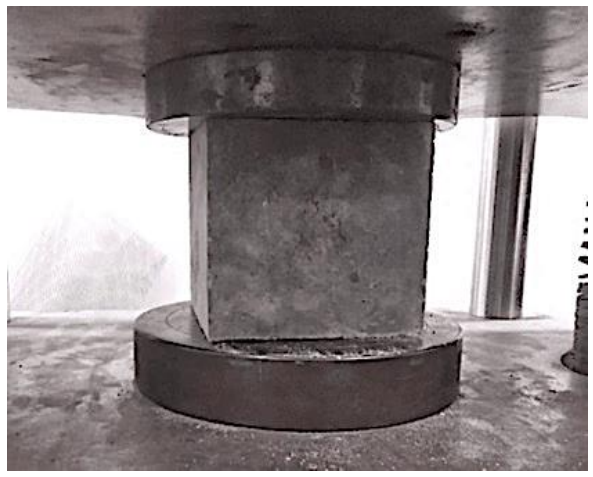

Figure 2 Set up for compression test

\subsection{Split Tensile Strength Testing}

Concrete weak tensile strength with high friableness causes it futile to contend against tension. The splitting tension tests are renowned indirect tests which is employed for measuring the tensile strength of concrete. The test was examined as per EN 12390-6 (2000). The tensile splitting strength is given by the formula shown below:

$$
f_{c t}=\frac{2 F}{\pi L d}
$$

Where, fct is the splitting tensile strength, [MPa]; $F$ is the maximum applied load indicated by testing machine, $[N]$; $L$ is the length, [mm]; $d$ is the cross-sectional dimension, in [ $\mathrm{mm}]$.

\subsection{Plastic Shrinkage Testing}

In this study, to examine the plastic shrinkage crack of plain concrete and JFRC guideline of ASTM C490 was followed accordingly. The concrete slab mold of dimension $500 \times 250 \mathrm{X}$ $75 \mathrm{~mm}$ was cast (Figure 3a). The concrete was set into the slab mold after mingling. Subsequently, the poured slab was kept with a specific ambience wherein a constant temperature of 37 $\pm 10 \mathrm{C}$ a relative humidity of $62 \pm 1 \%$ was maintained. Afterwards, the slabs were examined in a visual manner for any indications of cracking at every 30-min intermission and images were also entrapped for every stage to get clear crack profile. The slabs were taken out from the controlled environment after $24 \mathrm{~h}$. 


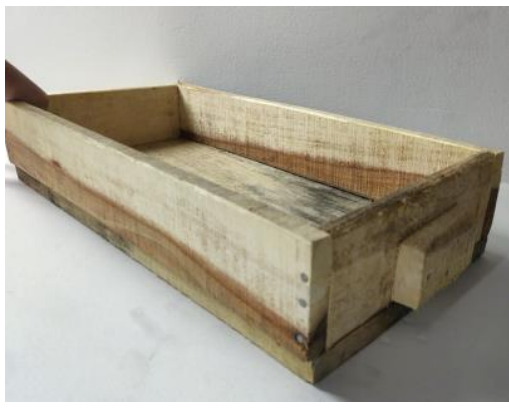

(a)

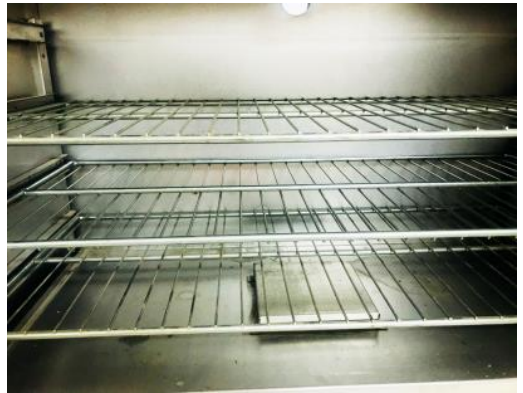

(b)

Figure 3 Mold for plastic shrinkage test $(500 \times 250 \times 75) \mathrm{mm}$; (b) Temperature controlled chamber

\subsection{RESULT AND DISCUSSION}

\subsection{Compressive Strength}

In this study, the concrete target strength was fixed to $35 \mathrm{MPa}$ using $\mathrm{ACl} 211$ (2009). Figures 4 and 5 illustrate the compressive failure and compressive strength between Jute Fiber Reinforced Concrete (JFRC) and plain concrete. The experimental results of compressive strength test demonstrated in Table 4. From the Figure 5, it was observed that, addition of jute fiber the compressive strength ameliorated up to $0.3 \%$ then reduced as fiber volume fraction augmented. The compressive strength of JFRC improves in a range from $6.5 \%$ to $12.4 \%$ for $15 \mathrm{~mm}$ length of jute fiber, whereas the strength of JFRC (25 mm length) increases in a range from $1.7 \%$ to $8.0 \%$. Highest amelioration of $12.4 \%$ compressive strength was noticed by incorporating $0.3 \%$ (15 $\mathrm{mm}$ length) fiber. It is observed that when jute fibers in discrete form present in the concrete, enlargement of crack is restricted and it changes its brittle mode of failure into a more ductile pattern (Figure 4). Darjole et al [17] reported that enhancement in compressive strength ranged from $3.25 \%$ to $21.4 \%$ due to combination of Steel and polypropylene fibers to the concrete. As a result, using $15 \mathrm{~mm}$ length of JFRC with $\leq 0.30 \%$ fiber addition culminates to more pledging combination for compressive strength enhancement.

Table 4 Test Results of Compressive strength

\begin{tabular}{|c|c|c|c|c|c|c|}
\hline $\begin{array}{l}\text { Fiber } \\
\text { Length } \\
(\mathrm{mm})\end{array}$ & $\begin{array}{c}\text { Type in } \\
\text { concrete }\end{array}$ & $\begin{array}{c}\text { Compressive } \\
\text { Strength at } 7 \text { days } \\
\text { (MPa) }\end{array}$ & $\begin{array}{l}\text { Compressive } \\
\text { Strength at } 28 \\
\text { days (MPa) }\end{array}$ & $\begin{array}{c}28 \text { days } \\
\text { Strength } \\
\text { Effectiveness }(\%)\end{array}$ & $\begin{array}{c}\text { Steel } \\
\text { fiber + Polypropylene } \\
\text { fiber* }\end{array}$ & $\begin{array}{l}\text { Compressive } \\
\text { Strength at } 28 \\
\text { days (MPa)* }\end{array}$ \\
\hline- & $\begin{array}{c}\text { Plain } \\
\text { Concrete }\end{array}$ & 21.023 & 36.5 & - & 0 & 33.21 \\
\hline \multirow[t]{3}{*}{15} & JF1 & 24.753 & 38.87 & 6.5 & $0.15 \% \mathrm{SF}+0.35 \% \mathrm{PF}$ & 35.43 \\
\hline & $\mathrm{JF} 2$ & 25.62 & 39.62 & 8.5 & $0.35 \% \mathrm{SF}+0.15 \% \mathrm{PF}$ & 37.01 \\
\hline & JF4 & 25.51 & 39.05 & 7.0 & $0 \% \mathrm{SF}+0.4 \% \mathrm{PF}$ & 34.29 \\
\hline \multirow[t]{4}{*}{25} & JF5 & 23.093 & 37.13 & 1.7 & $0.5 \% \mathrm{SF}+0 \% \mathrm{PF}$ & 35.66 \\
\hline & JF6 & 24.45 & 37.89 & 3.8 & - & - \\
\hline & JF7 & 24.93 & 39.42 & 8.0 & - & - \\
\hline & JF8 & 24.12 & 37.65 & 3.2 & - & - \\
\hline
\end{tabular}

Note: strength-effectiveness $(\%)=[($ strength of fiber concrete - strength of pure concrete) $/$ strength of pure concrete $] \times 100 \%$

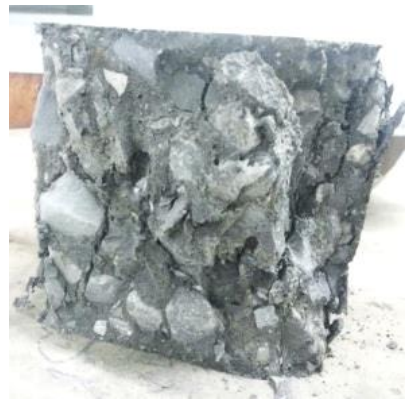

(a)

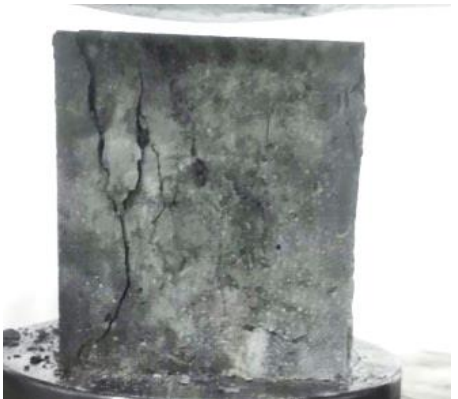

(b)

Figure 4 Specimen after Compression failure (a) Plain Concrete (b) JFRC $(0.1 \%)$ 


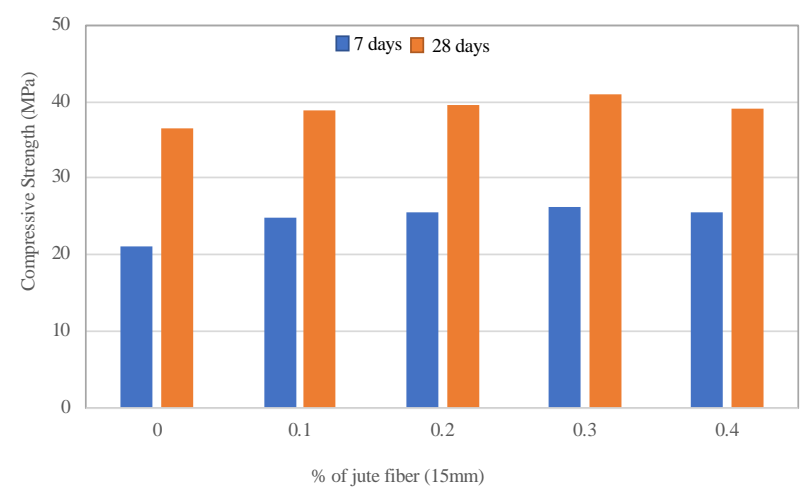

(a)

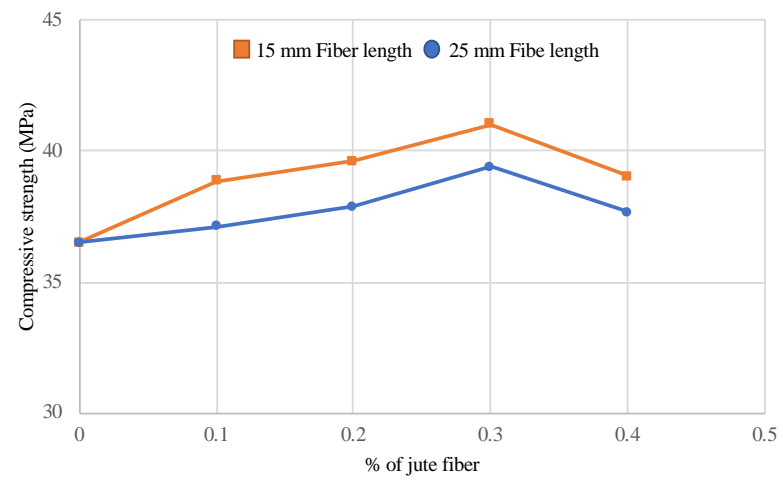

(c)

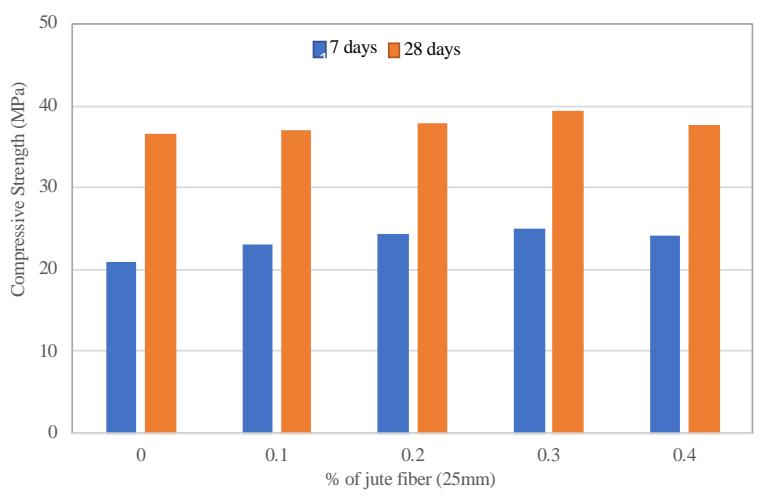

(b)

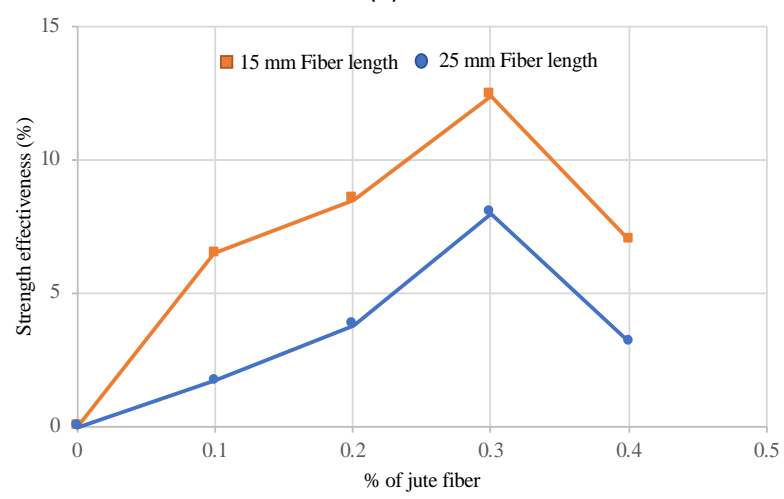

(d)

Figure 5 Variation of Compressive strength with fiber volume fraction (a) 15 mm Jute fiber (b) 25 mm Jute fiber (c) Comparison of strength between 15 $\mathrm{mm}$ and $25 \mathrm{~mm}$ length of Jute fiber (d) Comparison of strength increment between $15 \mathrm{~mm}$ and $25 \mathrm{~mm}$ length of Jute fiber

\subsection{Split Tensile Strength}

Test results of concrete split tensile strength test results are given in Table 5 and Figure 6. As the fiber content increased, the splitting tensile strength of JFRC augmented in a range from $40.4 \%$ to $58.2 \%$ for $15 \mathrm{~mm}$ length of jute fiber, whereas the splitting tensile strength of JFRC ( $25 \mathrm{~mm}$ length) ameliorated in a range from $3.2 \%$ to $41.8 \%$. Furthermore, incorporating $0.3 \%$ (15 mm length) fiber excellent result was attained and nearly $58.2 \%$ improvement in the tensile splitting strength was found. The fiber with short length and smaller amount impels the uniform distribution of fiber and hinder the occurrence of cracking the cube against tensile load. However, the concrete tensile strength reduction was observed for $>15 \mathrm{~mm}$ fiber length and $>0.30 \%$ dosing. In addition to, using higher amount of fibers $(0.4 \%)$ the split tensile strength of concrete was attenuated partly but it possessed high tensile strength in contrast to control concrete. A previous research on combination of steel fiber and polypropylene fiber exhibited significant improvement on splitting tensile strength about $13.2 \%$ when $0.25 \%$ polypropylene fiber was added with $0.75 \%$ steel fiber and then abatement of split tensile strength found when inclusion of polypropylene fiber was $0.4 \%$ (Table 5).

Table 5 Test Results of Tensile strength

\begin{tabular}{|c|c|c|c|c|c|c|}
\hline $\begin{array}{l}\text { Fiber } \\
\text { Length } \\
(\mathrm{mm})\end{array}$ & $\begin{array}{l}\text { Type in } \\
\text { concrete }\end{array}$ & $\begin{array}{l}\text { Tensile splitting } \\
\text { Strength at } 7 \text { days } \\
\text { (MPa) }\end{array}$ & $\begin{array}{l}\text { Tensile splitting } \\
\text { Strength at } 28 \text { days } \\
\text { (MPa) }\end{array}$ & $\begin{array}{c}28 \text { days } \\
\text { Strength } \\
\text { Effectiveness (\%) }\end{array}$ & $\begin{array}{c}\text { Steel } \\
\text { fiber + Polypropylene } \\
\text { fiber* }\end{array}$ & $\begin{array}{c}\text { Tensile } \\
\text { splitting Strength } \\
\text { at } 28 \text { days (MPa)* }\end{array}$ \\
\hline- & Plain Concrete & 1.17 & 2.13 & - & 0 & 2.73 \\
\hline \multirow[t]{4}{*}{15} & JF1 & 1.88 & 2.99 & 40.4 & $0.8 \% \mathrm{SF}+0.2 \% \mathrm{PF}$ & 2.99 \\
\hline & JF2 & 1.98 & 3.20 & 50.2 & $0.75 \% \mathrm{SF}+0.25 \% \mathrm{PF}$ & 3.09 \\
\hline & JF3 & 2.40 & 3.37 & 58.2 & $0.7 \% \mathrm{SF}+0.3 \% \mathrm{PF}$ & 2.94 \\
\hline & JF4 & 1.93 & 3.02 & 41.8 & $0 \% \mathrm{SF}+0.4 \% \mathrm{PF}$ & 2.89 \\
\hline \multirow[t]{4}{*}{25} & JF5 & 1.30 & 2.20 & 3.2 & - & - \\
\hline & JF6 & 1.72 & 2.79 & 30.9 & - & - \\
\hline & JF7 & 2.04 & 3.02 & 41.8 & - & - \\
\hline & JF8 & 1.50 & 2.32 & 8.9 & - & - \\
\hline
\end{tabular}

Note: strength-effectiveness $(\%)=[($ strength of fiber concrete - strength of pure concrete) $/$ strength of pure concrete $] \times 100 \%$. 


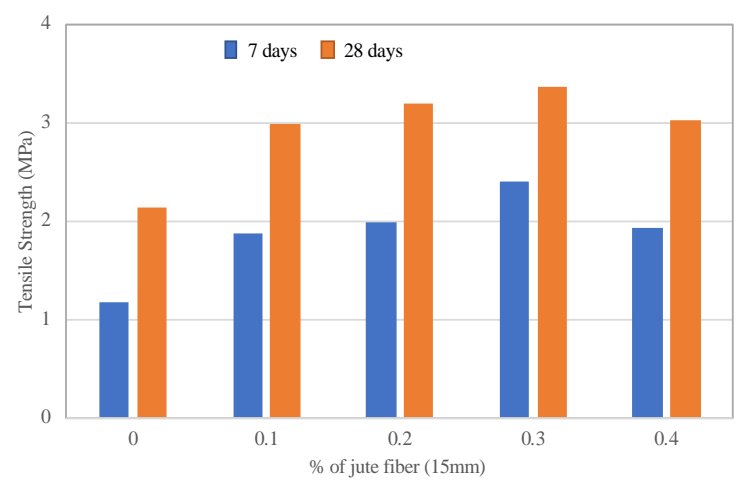

(a)

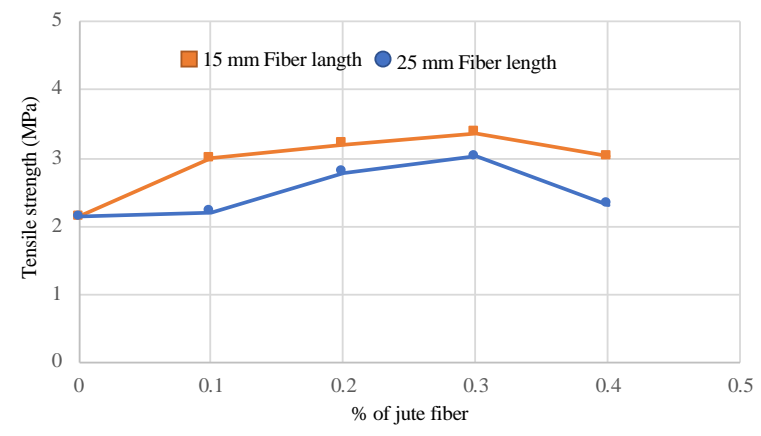

(c)

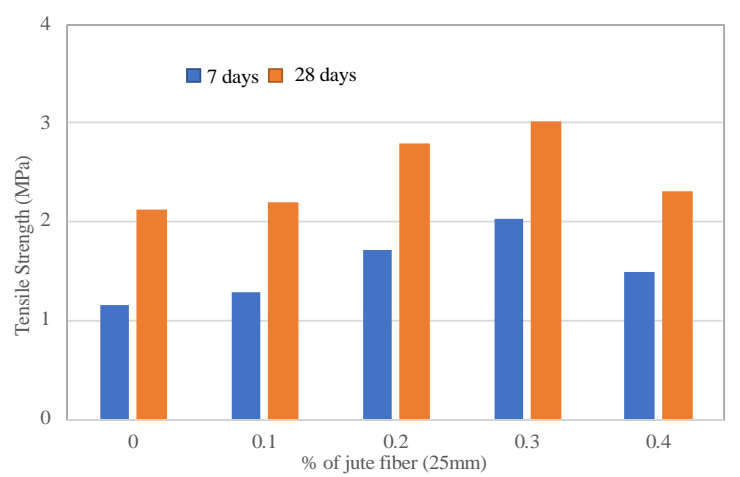

(b)

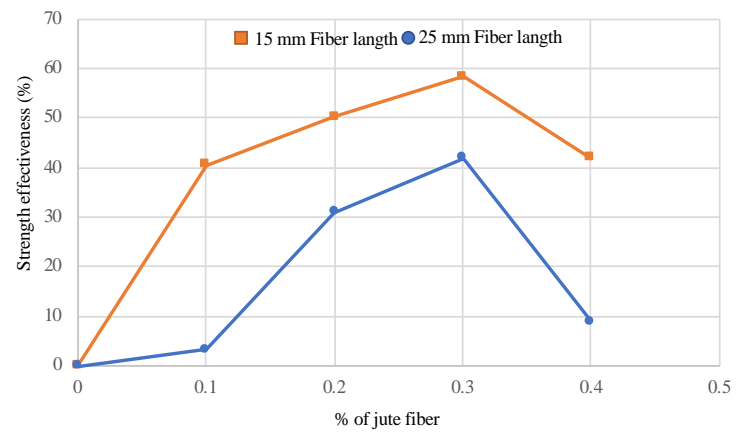

(d)

Figure 6: Variation of tensile strength with fiber volume fraction (a) $15 \mathrm{~mm}$ Jute fiber (b) $25 \mathrm{~mm}$ Jute fiber (c) Comparison of strength between $15 \mathrm{~mm}$ and $25 \mathrm{~mm}$ length of Jute fiber (d) Comparison of strength increment between $15 \mathrm{~mm}$ and $25 \mathrm{~mm}$ length of Jute fiber

\subsection{Effect of Jute Fiber on Brittleness of Concrete}

The brittleness is a significant indicator to evaluate concrete performance. The tension-compression ratio can represent the brittleness of concrete $[4,5]$; the greater the ratio, the smaller the brittleness. A summary of tension to compression ratio of Jute fiber reinforced concrete (JFRC) is shown in Table 6 and Figure 7.
The ratio steadily growing with the increase of the fiber amount. Adding JF abates the brittleness of concrete compared to plain concrete, brittleness of concrete reduced in a range of $32.8 \%$ to $41.3 \%$ for $15 \mathrm{~mm}$ length of JF whereas with the addition of $25 \mathrm{~mm}$ length of JF, brittleness of concrete reduced in a range of $1.7 \%$ to $32.8 \%$.

Table 6 Test Results of tensile to compression ratio

\begin{tabular}{|c|c|c|c|c|c|}
\hline \multicolumn{2}{|c|}{$\begin{array}{l}\text { Length of fiber } \\
\qquad(\mathrm{mm})\end{array}$} & \multirow{2}{*}{$\begin{array}{c}\begin{array}{c}\text { Type of } \\
\text { concrete }\end{array} \\
\text { Plain Concrete }\end{array}$} & \multirow{2}{*}{$\begin{array}{c}\text { Fiber content (\%) } \\
0\end{array}$} & \multirow{2}{*}{$\begin{array}{c}\text { Tensile to } \\
\text { compression ratio } \\
0.058\end{array}$} & \multirow{2}{*}{$\begin{array}{c}\text { Reduction of } \\
\text { Brittleness of } \\
\text { Concrete (\%) } \\
-\end{array}$} \\
\hline & - & & & & \\
\hline \multirow{8}{*}{$\begin{array}{l}\text { Jute } \\
\text { Fiber }\end{array}$} & \multirow{4}{*}{15} & JF1 & 0.1 & 0.077 & 32.8 \\
\hline & & JF2 & 0.2 & 0.081 & 39.7 \\
\hline & & JF3 & 0.3 & 0.082 & 41.3 \\
\hline & & JF4 & 0.4 & 0.078 & 34.5 \\
\hline & \multirow{4}{*}{25} & JF5 & 0.1 & 0.059 & 1.7 \\
\hline & & JF6 & 0.2 & 0.074 & 27.5 \\
\hline & & JF7 & 0.3 & 0.077 & 32.8 \\
\hline & & JF8 & 0.4 & 0.062 & 7.0 \\
\hline
\end{tabular}

When a crack is formed, fibers that bridge the crack prevent it from opening more. It is worth noting that adding JF of aspect ratio $300(15 \mathrm{~mm})$ is much better for suppressing the brittleness than JF of aspect ratio $500(25 \mathrm{~mm})$. Moreover, tensile failure pattern between plain concrete and Jute fiber reinforced concrete is different as shown in Figure 8. In case of plain concrete, failure is completely splitting type and concrete split in two parts whereas in case of fiber reinforced concrete due to holding capacity of fiber it prevents the concrete from splitting. 


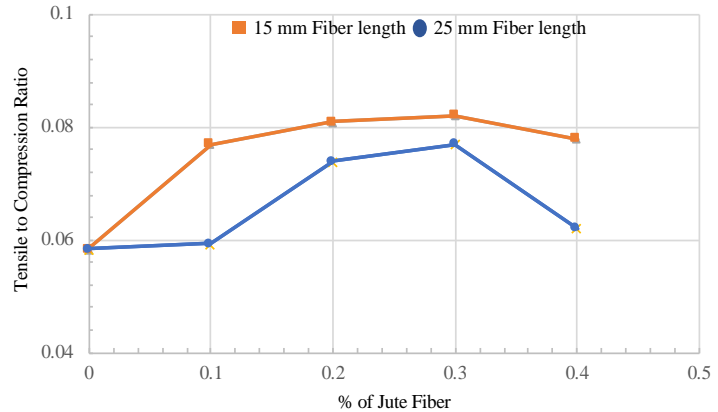

(a)

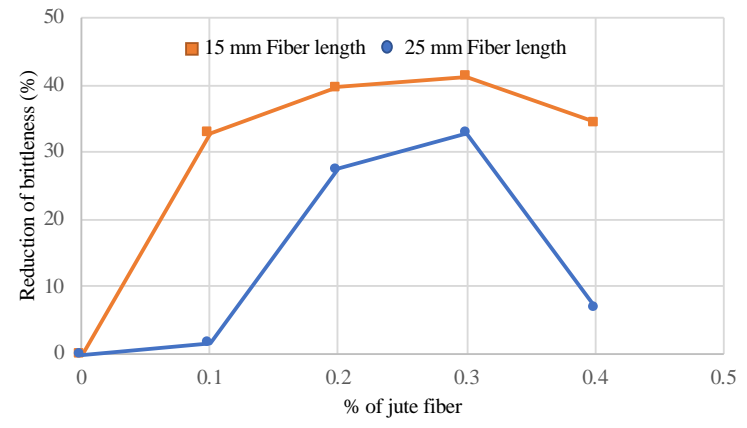

(b)

Figure 7: Variation of tensile to compression ratio with fiber volume fraction (a) comparison between $15 \mathrm{~mm}$ Jute fiber and $25 \mathrm{~mm}$ jute fiber (b) Comparison of reduction of brittleness of concrete between $15 \mathrm{~mm}$ and $25 \mathrm{~mm}$ length of Jute fiber

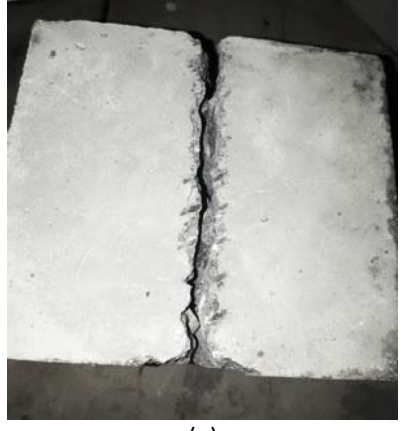

(a)

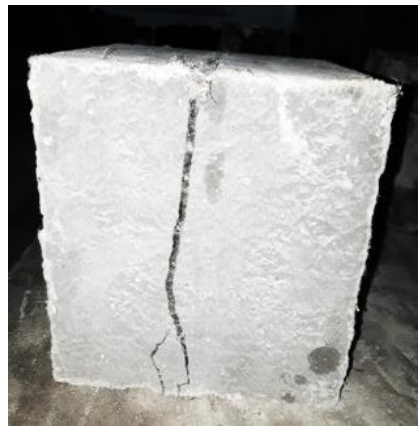

(b)

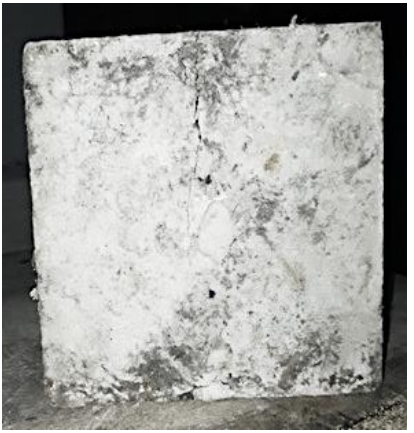

(c)

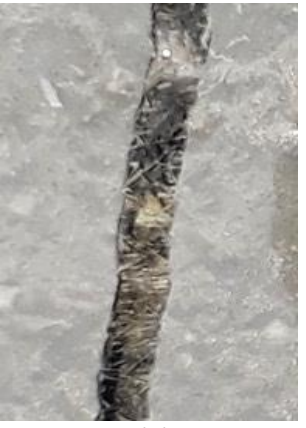

(d)

Figure 8: Specimen after tension failure (a) Plain Concrete (b) JFRC

(0.3) (d) Fracture

of fiber in tensile failure

\subsection{Shrinkage Test}

Experimental observations of plastic shrinkage crack of JFRC are shown in Figure 9. Addition of $0.3 \%$ jute fiber with $15 \mathrm{~mm}$ length (Figure 9d) the propagation of crack was significantly reduced. After the crack generation the image was trapped by camera. Furthermore, to get the clear crack outline the trapped images were updated with image analysis software. After that to measure the crack area the updated images were analyzed by image ' $\mathrm{j}$ ' software (Figure 10). The analyzed results are shown Table 7 and Figure 10. The percentage of crack attenuated with the addition of Jute Fiber. By adding, 0.30\%$0.4 \%$ fiber (by volume) there was no sign of cracks on concrete slab. However, inclusion of $0.10-0.2 \%$ fibers, some micro crack was observed on the slab. Without addition of fiber plastic shrinkage crack in plain concrete was highly visible with the shortest possible time after the concrete casted. Incorporation of jute fiber $(0.1-0.4 \%)$ the shrinkage crack is abated by $75-$ $100 \%$. Moreover, shrinkage crack width was found within tolerable limit ( $\mathrm{ACl} 224: 3 \mathrm{~mm}$ ) for JFRC in contrast to plain concrete. Previous research carried out by Sivakumar and Santhanam (2007) on plastic shrinkage crack using combination of metallic and non-metallic fiber of $0.5 \%$ (combination of steel and polypropylene) reinforced concrete and found 49\%-99\% decrease in plastic shrinkage crack. Therefore, abatement of shrinkage cracking with the addition of Jute fiber in concrete is confirmed.

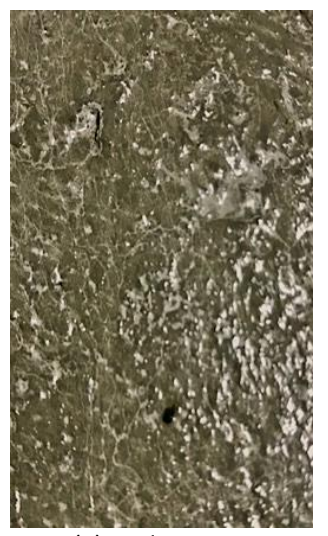

(a) Plain concrete

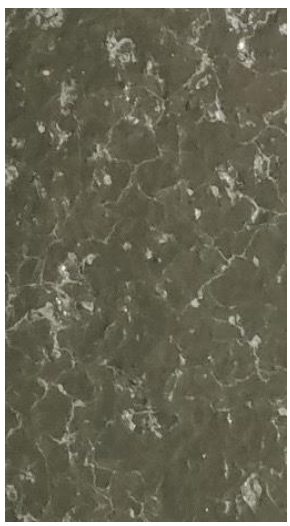

(b) JF1 (0.1\%)

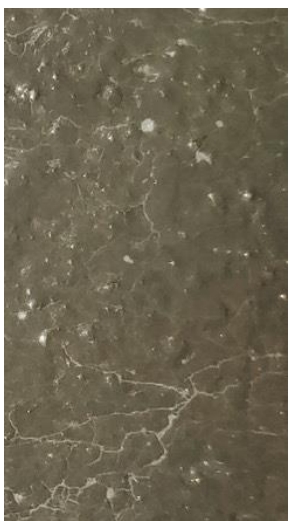

(c) JF2 (0.2\%)

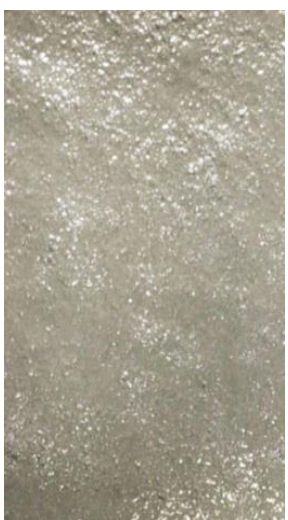

(d) JF3 (0.3\%)

Figure 9 Plastic shrinkage crack in concrete slab (area covered 8.0" x 5.8") 


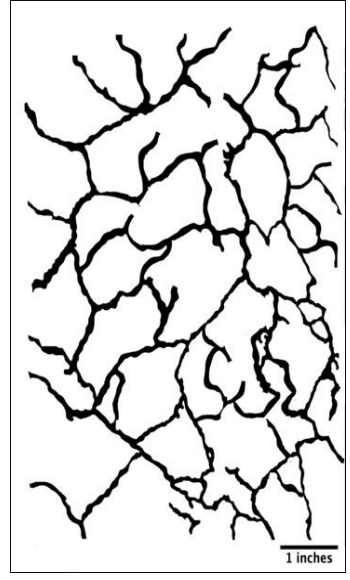

(a) Plain concrete (Crack area: 5.87 inch $^{2}$ )

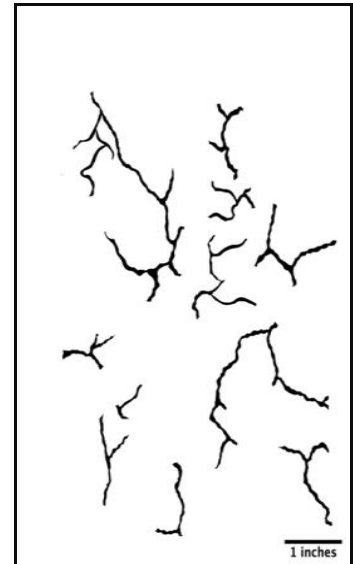

(b) JF1 (Crack area: 1.47 inch $^{2}$ )

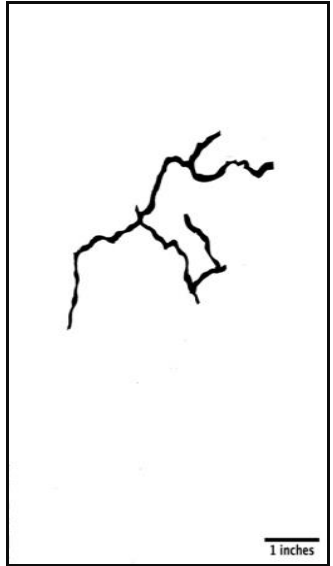

(c) JF2 (Crack area: 0.79 inch $^{2}$ )

Figure 10 Image analysis for shrinkage crack (area covered 8.0" x 5.8")

Table 7 Test results of Shrinkage crack of Jute fiber reinforced concrete (JFRC)

\begin{tabular}{|c|c|c|c|c|}
\hline $\begin{array}{c}\text { Type of } \\
\text { concrete }\end{array}$ & $\begin{array}{c}\text { Percentages of crack } \\
\text { (\%) }\end{array}$ & $\begin{array}{c}\text { Decrease of } \\
\text { crack (\%) }\end{array}$ & $\begin{array}{c}\text { Polypropylene } \\
\text { fiber (PF) + steel } \\
\text { Fiber(SF)* }\end{array}$ & $\begin{array}{c}\text { Decrease of } \\
\text { crack (\%)* }\end{array}$ \\
\hline Plain concrete & 12.6 & --- & $0 \%$ & $-15 \%$ \\
\hline JF1 & 3.15 & 75 & $0 \%+0.5 \%$ & 48.58 \\
\hline JF2 & 1.7 & 86.5 & $0.12 \%+0.38 \%$ & 60.41 \\
\hline JF3 & 0.0 & 100 & $0.25 \%+0.25 \%$ & 78.05 \\
\hline JF4 & 0.0 & 100 & $0.5 \%+0 \%$ & 99.87 \\
\hline
\end{tabular}

* Sivakumar and Santhanam (2007).

\subsection{CONCLUSIONS}

This paper represented experimental results of compressive strength, tensile strength and plastic shrinkage crack of concrete using 'Natural (Jute)' fiber. The following conclusions can be summarized below:

- Inclusion of $15 \mathrm{~mm}$ length of jute fiber the compressive strength increases from $6.5 \%-12.4 \%$ with respect to plain concrete whereas the compressive strength increases from $1.7 \%$ - $8 \%$ with the addition of $25 \mathrm{~mm}$ length of Jute fiber. The optimum content of jute fiber is $0.3 \%$ with the length of $15 \mathrm{~mm}$ of which the maximum increment of compressive strength was found $12.4 \%$.

- Enhancement of tensile strength was noticed by $40 \%$ - 58\% compared to the plain concrete with the addition of jute fiber $(15 \mathrm{~mm})$ in concrete whereas in case of $25 \mathrm{~mm}$ length of jute fiber the tensile strength increases from $3.3 \%$ - $42 \%$ with respect to plain concrete. The optimum content of jute fiber for tensile strength is found $0.3 \%$ with the length of $15 \mathrm{~mm}$ of which the maximum enhancement was found $58 \%$.

- Using jute fiber of $15 \mathrm{~mm}$ length concrete brittleness abated from $32.8 \%-41.3 \%$ with respect to the plain concrete whereas by adding $25 \mathrm{~mm}$ length of jute fiber the brittleness reduced from $1.7 \%-32.8 \%$ in contrast to the plain concrete.

- By incorporating jute fiber (15 mm) of 0.1-0.4\%, plastic shrinkage cracks were attenuated by $75-99 \%$ in contrast with the control concrete.

- Finally, incorporation of $15 \mathrm{~mm}$ length of Jute fiber at $0.3 \%$ volumetric addition was proved to be advantageous taking into account concrete compressive (12.4\% increase) strength, tensile (58\% increase) strength, reduction of brittleness of concrete $(41 \%)$ and plastic shrinkage $(99 \%$ crack reduction) properties.

\section{Acknowledgements}

The cooperation granted by the laboratory of Ahsanullah University of Science \& Technology (AUST) is gratefully appreciated.

\section{References}

[1] EN 12390-03, 2009. Testing hardened concrete, part-3: compressive strength test of concrete. In: European Committee for Standardization, Avenue Marnix 17, B-1000 Brussels, Belgium. 
[2] EN 12390-06, 2000. Testing hardened concrete, part-6: tensile splitting test of concrete. In: European Committee for Standardization, Avenue Marnix 17, B-1000 Brussels, Belgium.

[3] Physical and Chemical Properties of Jute, Textile Engineering, Available at: [Link], [Accessed at 4th September, 2019]

[4] W. Li, Z. Huang, X. C. Wang et al. 2014. Study on tension and compression ratio and discount ratio of rubber modified silica fume concrete, Applied Mechanics and Materials, 670-671: 396-400,.

[5] R. Li, X. H. Zhang, and Y. F. Meng, 2014. Study of performance on reduce fragility and increase the toughness of fly ash ceramsite concrete, Advanced Materials Research, 997: 120-123

[6] $\mathrm{ACl}$ 211.1, 2009. Standard Practice for Selecting Proportions for Normal, Heavyweight and Mass Concrete. American Concrete Institute, Farmington Hills, MI, 48331-3439 USA.

[7] $\mathrm{ACl} 224.1 \mathrm{R}, 2007$. Causes, Evaluation, and Repair of Cracks in Concrete Structures. American Concrete Institute, Farmington Hills, MI, 48331-3439, USA.

[8] Sivakumar, A., Santhanam, M., 2007. A quantitative study on the plastic shrinkage cracking in high strength hybrid fibre reinforced concrete. Cement Concrete Composite, 29: 575-581.

[9] Vairagade S V and Kene S K, 2013. Strength of Normal Concrete Using Metallic and Synthetic Fibers, Procedia Engineering, Elsevier, 51: 132140.

[10] Darole ER. J. S, Kulkarni V.P, Shaikh A.P and Gite B.E. 2013. Effect of hybrid fiber on mechanical properties of concrete. International Journal of Engineering Research and Applications (IJERA), 3: 14081411.

[11] Sivakamasundari S and Balamurugan S. 2019. Mechanical Properties of Hybrid Fiber Concrete, International Journal of innovative Technology and Exploring Engineering (IJITEE), 8: 146-150.

[12] Kannan.S. 2016. Study on Strength Properties of hybrid Fiber Reinforced Concrete, International Journal of Scientific \& Engineering Research,-7: 61-68. 2229-5518.
[13] Kanagavel R and Arunachalam K. 2015. Experimental Investigation on Mechanical Properties of Hybrid Fiber Reinforced Quaternary Cement Concrete, Journal of Engineered Fibers and Fabrics, 10: 139147.

[14] Madhuri M, Chandra J K and Bharath B B. 2017. Comparison of Performance of Non Metallic Fibre Reinforced Concrete and Plain Cement Concrete, International Research Journal of Engineering and Technology (IRJET), 4:-3393.

[15] Kim J S, Cho C G, Moon H J, Kim H, Lee S J and Kim W. 2017. Experiments on Tensile and Shear Characteristics of Amorphous Micro Steel (AMS) Fibre-Reinforced Cementitious Composites, International Journal of Concrete Structures and Materials, 11: 647655.

[16] Dinh N H, Choi K K and Kim H S. 2016. Mechanical Properties and Modeling of Amorphous Metallic FiberReinforced Concrete in Compression, International Journal of Concrete Structures and Materials, 10: .221-236.

[17] Zakaria M, Ahmed M, Hoque M M and Islam S. 2016. Scope of using jute fiber for the reinforcement of concrete material, Textiles and Clothing Sustainability, 2:11.

[18] Islam G M S, Gupta S D, 2016, Evaluating plastic shrinkage and permeability of polypropylene fiber reinforced concrete. International Journal of Sustainable Built Environment, Elsevier, 5: 345-354.

[19] T. Sai Vijaya Krishna, B. Manoj Yadav. 2016. A comparative study of jute fiber reinforced concrete with plain cement concrete, International Journal of Research in Engineering and Technology, ISSN: 2321-7308, 5: 111-116

[20] Mohammed, T. U., Hasnat, A., Awal, M. A., \& Bosunia, S. Z. 2014. Recycling Of Brick Aggregate Concrete As. Coarse Aggregate. Journal of Materials in Civil Engineering, 27(7): 1-9 